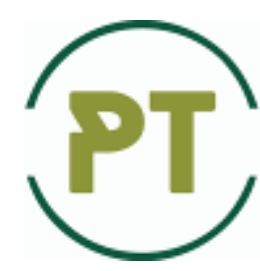

\title{
Tribological researches of electroerosive processing of steel details of cars
}

\author{
D.D. Marchenko*, K.S. Matvyeyeva \\ Mykolayiv National Agrarian University, Mykolayiv, Ukraine \\ *E-mail:marchenkodd@mnau.edu.ua
}

\begin{abstract}
The article considers the technology of electroerosive treatment of steel friction pairs and presents the results of experimental studies. Analysis of experimental studies has shown that an increase in the anode-cathode voltage leads to a sharp decrease in the microhardness of the surface layer. The study also allowed to determine the characteristic size of the structural elements, the height parameters of the surface roughness. The elemental composition of the initial surface of the sample made of steel 15HGN2TA differs from the composition of the coatings and surface layers of the samples modified by electroerosive treatment with different electrodes. In the mode of operation of the "anode - cathode" system on the cathode surface due to dissipative processes, a thin layer of coating of a stable modified structure is formed. It is shown that the height of surface irregularities in the areas after friction is higher than in the areas of the surface outside the friction track, which is associated with the formation on the surface of the samples of the friction transfer film. It was found that the frictional interaction of steel samples treated by electroerosion method forms a thin film on the friction surface of steel samples, which leads to a change in the topography of surfaces with increasing height of microroughnesses and structuring of the transfer film in the sliding direction. The influence of electroerosive treatment of steel surfaces on the wear resistance of the metal-polymer tribosystem was established and the optimal treatment modes were obtained: voltage $\mathrm{U}=145-150 \mathrm{~V}$, capacitor capacity $\mathrm{C}=225-230 \mu \mathrm{F}$, treatment duration $\mathrm{t}=3-4 \mathrm{~min} / \mathrm{cm}^{2}$, providing the greatest reduction in speed wear of the polymer counterbody and recommended in the development of technological processes of electroerosive treatment.
\end{abstract}

Key words: wear, electrode, roughness, wear resistance, friction steam, coating, electroerosive treatment.

\section{Introduction}

Reliability and efficiency of machines and technological equipment are determined mainly by wear resistance and durability of parts of tribosystems. Depending on the operating conditions of the products, various methods of surface hardening of steels and alloys are used in the industry, such as surface plastic deformation, chemical-thermal treatment, formation of hardening wear-resistant coatings (microarc oxidation, spraying, etc.), high-energy methods etc.) and their various combinations. All known methods of surface hardening have their advantages and scope, but do not fully meet modern requirements for efficiency, versatility and costeffectiveness of technological processes. Therefore, the development of an effective, fairly simple to master in industrial production and economic method of increasing wear resistance remains an urgent scientific and practical task. The most promising are the methods of surface modification of parts of tribosystems with the use of highly concentrated energy flows, which include electroerosive treatment (EET), which allows to obtain coatings with high physical, mechanical and tribotechnical properties.

Combined surface hardening methods allow to create coatings with high predetermined performance properties [1]. Thus, surface alloying with subsequent nitriding of low-alloy steels allows to increase the characteristics of mechanical strength above the level of properties of high-alloy steels. In [2] the problems of increasing the wear resistance of a long tool by the method of combined hardening, which includes nitriding and coating $(\mathrm{Ti}, \mathrm{Nb}, \mathrm{Al}, \mathrm{N})$ are considered. Production tests have shown that the combined strengthening of broaches on the offered modes allows to increase in 2-4 times their stability in comparison with not strengthened. 
The combination of methods of physical cathodic-arc and chemical deposition from the gas phase in the treatment of plunger pairs of high pressure fuel pumps made of steel 25X5MA, allows to obtain a coating with high hardness, wear resistance and corrosion resistance [3]. The essence of the method is the destruction of carbon gas molecules as a result of their collisions with high-energy ions generated by high-current pulsed cathode-arc discharge on the surface of the graphite target. The products of this interaction settle on the substrate and form a wear-resistant coating. It is established that the coefficient of friction of surfaces with such a coating in the conditions of extreme lubrication is $0.10-0.12$ and practically does not change in the presence of impurities of water and fine abrasive particles, while for surfaces without coatings the coefficient of friction increases by 1,4 times in the presence of impurities.

In [4-6] it was shown that the preliminary application on the surface of the alloying sublayer with concentrate by the method of electroerosive doping with its subsequent remelting by an electric arc in a carbon dioxide environment allows to significantly change the performance of steel St3 in the desired direction.

Electroerosive treatment of steel 45 with a hard alloy VK6M, chromium and molybdenum with subsequent laser hardening reduces the wear intensity of coatings formed by hard alloy by $70 \%$, and coatings formed by $\mathrm{Cr}$ and Mo - respectively 3.5 and 3 times, compared with untreated steel [7, 8].

An experimental study of the process of microarc cementation of steel products in powder media was carried out in $[9,10]$. The use of coal powder intensifies the process of diffusion saturation with carbon and the formation of a diffusion layer up to $0.3 \mathrm{~mm}$ deep occurs in the course of $2 \ldots 3$ minutes, which reduces the cementation process by hundreds of times.

Therefore, the purpose of work consists in establishment of laws of formation of wear-resistant coverings on a steel substrate by a method of electroerosive processing providing increase of wear resistance of steel details of knots of friction of cars.

To achieve this goal it is necessary to solve the following tasks:

1. To conduct an experimental study of the influence of the chemical composition of the electrode material (anode) on the structure and phase composition of coatings formed on steel samples.

2. Investigate the dependences of microhardness and tribotechnical properties of coatings on the composition of the alloying electrode material and energy modes of electroerosive treatment.

3. By the method of contact atomic force microscopy to investigate the influence of the composition of the material of the alloying electrodes and the modes of electroerosive treatment on the dimensions of the structural elements of the formed coatings and the roughness parameters of the treated surface.

4. Carry out an optimization study of EET modes and develop practical recommendations for the appointment of optimal technological modes of electroerosive treatment of steel 15HGN2TA, providing the highest wear resistance of metal-polymer friction pairs.

\section{Research methodology}

As an object of experimental research used structural alloy steel 15HGN2TA, which is widely used for the manufacture of gears, axles, bushings, shafts of gearboxes, multi-purpose tracked and wheeled vehicles and other equipment. To increase the mechanical properties of steel 15HGN2TA use chemical-thermal treatment followed by heat treatment, which significantly complicates and increases the duration of the technological process of manufacturing parts.

Processing of samples was carried out on installations for electroerosive processing of models IMEI-022-1ME8 and IMEI-1001-1ME8, providing technological modes: anode-cathode voltage $\mathrm{i}=40-160 \mathrm{~V}$; bit capacitance of capacitors $\mathrm{C}=34-240 \mathrm{uF}$.

The surfaces of steel samples were treated with various alloying electrodes $(\mathrm{AE})$ : standard electrode brand T15K6 (TiC-15\%, Co-6\%, WC - 79\%); electrode IMX21 (WC-Co-50\%, Ni-Cr-B-Si-50\%); electrode Sh21 with mineral raw materials of the Far East region based on scheelite concentrate (TiC-60\%, Ni-Cr-Al-30\%, SC (scheelite concentrate CaWO4) - 10\%). The choice of alloying electrodes was made on the basis of previous studies.

The research method included the study of the influence of the material of the alloying electrode and technological modes of processing on the microhardness and thickness of the coatings formed during electroerosive processing. The microhardness of the molded surface layers was determined using a microhardness tester PMT-3M under load on an indenter of $0.49 \mathrm{~N}$. The thickness of the applied coatings was determined on a horizontal optimeter IKG-3 relative measurement method.

The study of the structure and phase composition of the modified surface layer of steel 15HGN2TA after electroerosive treatment was performed by X-ray phase analysis of the initial and modified samples on a diffractometer D8 ADVANCE (Bruker) in $\mathrm{Cu}-\mathrm{K}_{\alpha}$ radiation at angles $5^{0} \ldots 120^{\circ}$.

Using a scanning probe microscope NTEGRA Prima (NT-MDT) in the mode of contact atomic force microscopy (k-AFM) studied the microrelief and determined the characteristic dimensions of the structural surface elements of the initial samples and samples modified by EET different electrodes, as well as IMX2 electrode in different modes after friction and wear tests. Mathematical post-processing of the obtained results was carried out using the modular program Gwyddion. 
To study the elemental composition of the initial surface of steel 15HGN2TA and surface layers modified by EET with different electrodes, as well as coatings formed by the electrode IMX2 in different modes after tribotechnical tests used a scanning electron microscope Jeol JCM - 5700 and X-ray energy dispersion spectrometer.

Studies of the characteristics of tribotechnical properties were performed on a special installation created on the basis of a desktop drilling machine according to the friction scheme "finger-disk" at a contact pressure $\mathrm{P}=2.66 \mathrm{MPa}$ and a sliding speed $\mathrm{V}=1.20 \mathrm{~m} / \mathrm{s}$. Cylindrical fingers made of PTFE-based composite material were used as counter-samples.

\section{Research results}

From the diagrams (Fig. 1) it is seen that with increasing energy regimes EET: voltage from $80 \mathrm{~V}$ to $160 \mathrm{~V}$ and capacity from $34 \mu \mathrm{F}$ to $240 \mu \mathrm{F}$, the thickness of the coatings increases with any material LE. In this case, when processing the electrode T15K6, the coating thickness increases by $48.6 \%$, when processing the electrode IMX2 - by $75 \%$, when processing the electrode W2 - by $83.3 \%$.

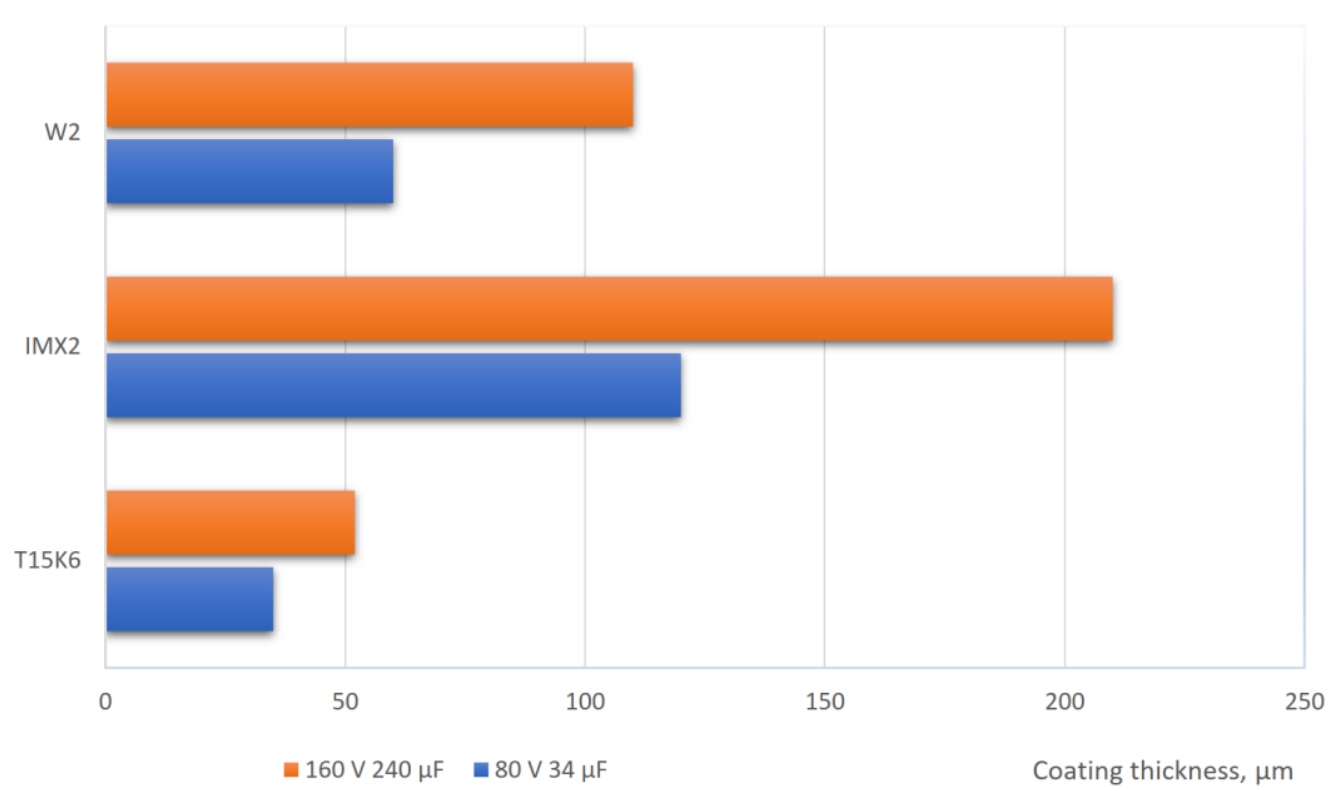

Fig. 1. The thickness of the coatings of the samples of steel 15HGN2TA with different electrode materials

The diagrams also show that when the EET electrode IMX2 based on tungsten carbide with the addition of components that form with the base material unlimited solid solutions, the largest coating thickness $(210 \mu \mathrm{m})$. This can be explained by the fact that the introduction of boron and silicon in the composition of LE slows down the formation of oxide films in the molded structure, which has a positive effect on the continuity and increase the thickness of the coating. In addition, the introduction of boron reduces the erosion resistance of LE, as a result, increases the mass transfer of electrode material to the treated surface. The use of the electrode W2 also leads to the formation of coatings that exceed the thickness of the coatings formed by the electrode brand T15K6, 1.7-2 times. This is due to the fact that the mineral raw material (scheelite concentrate) in the electrode material creates a protective atmosphere in the EET zone, preventing the burning of erosion particles and contributing to the intensification of mass transfer of the electrode material. The obtained results allow to use EET to restore worn surfaces of precision friction pairs within $100 \mu \mathrm{m}$.

Analysis of experimental dependences of microhardness of coatings on 15HGN2TA steel samples, anode-cathode voltage and capacitor discharge capacity, showed that increasing energy treatment regimes differently affects the nature of changes in microhardness of coatings when changing the material of the alloying electrode (Fig. 2, 3).

The highest values of microhardness of coatings (HB 900...1080) were obtained using electrodes IMX2 and T15K6. The greatest effect of increasing the microhardness is provided by the EET electrode IMX2 with a voltage of $\mathrm{U}=140 \mathrm{~V}$ and a capacity of $\mathrm{C}=120 \mu \mathrm{F}$. When treated with the electrode T15K6, the maximum microhardness is obtained at a voltage $\mathrm{U}=120 \mathrm{~V}$ and a capacity of $\mathrm{C}=150 \mu \mathrm{F}$. A further increase in the anodecathode voltage leads to a sharp decrease in the microhardness of the surface layer.

These results show that the elemental composition of the initial surface of the sample made of steel 15HGN2TA differs from the composition of the coatings and surface layers of the samples modified by EET by different electrodes. In the modified samples the presence of a number of elements of steel 15HGN2TA is not established: chromium, manganese and nickel at processing by the T15K6 electrode, chromium and manganese 
at processing by the $\mathrm{Sh} 2$ electrode, manganese and titanium at processing by the IMH2 electrode. The presence of tungsten (LE T15K6), oxygen (LE SH2) and silicon (LE IMH2) was established, which can be explained by the erosion of alloying elements and their low concentration in steel, as well as the interaction of electrode elements with steel.

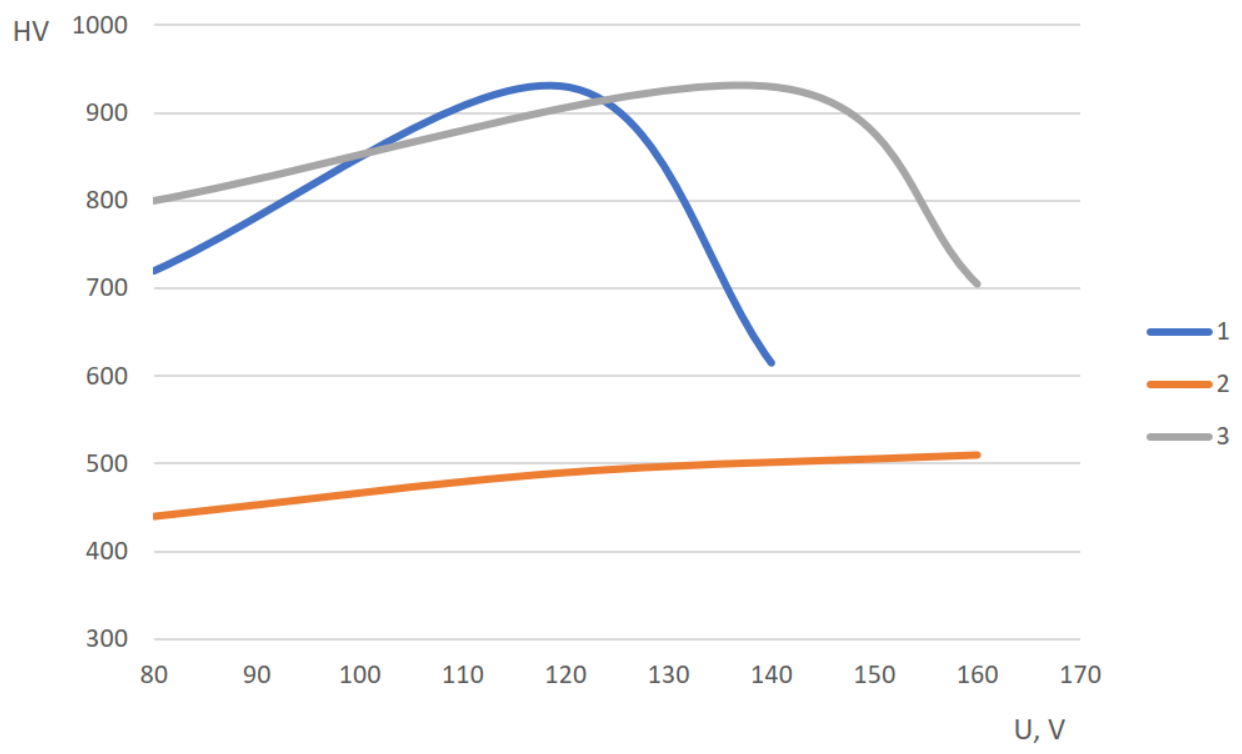

Fig. 2. The dependence of the microhardness of the surface layers of the samples modified by EET by different electrodes, from anode-cathode voltage at $\mathrm{C}=34 \mu \mathrm{F}$ : 1 - T15K6; 2 - W2; 3 - IMX2

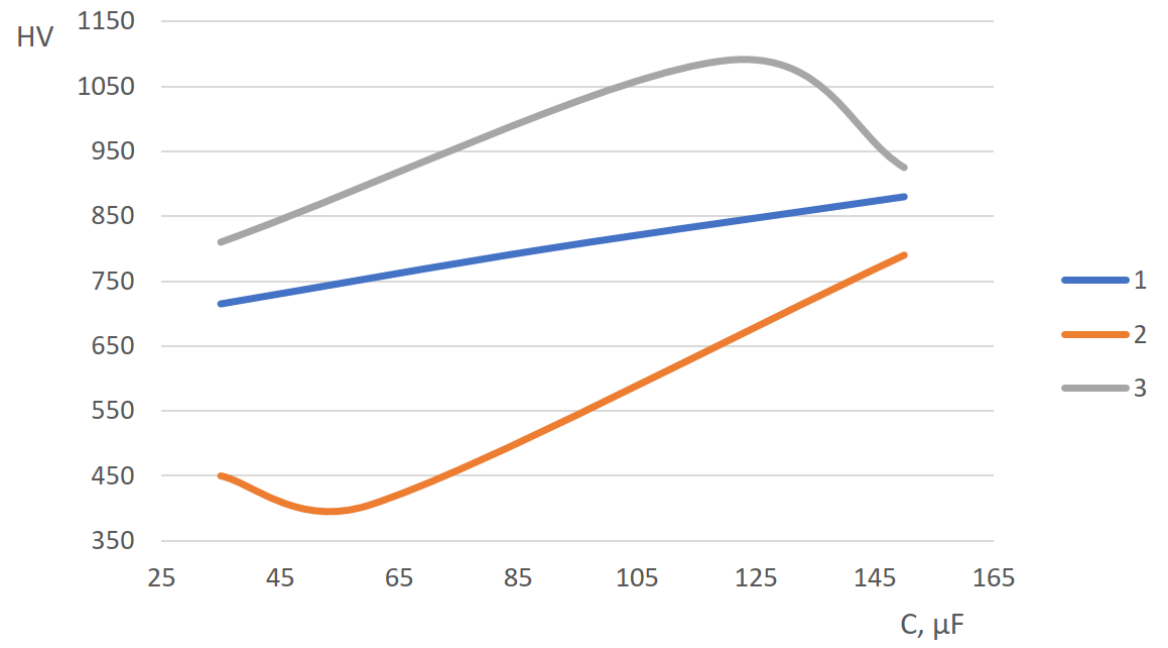

Fig. 3. The dependence of the microhardness of the surface layers of the samples modified by EET by different electrodes on the discharge capacity at $\mathrm{U}=80 \mathrm{~V}: 1$ - T15K6; 2 - W2; 3 - IMX2

Quantitative chemical composition of the initial (unmodified) sample and coatings on steel samples treated with electrodes T15K6, Sh2 and IMH2, are given in Table 1.

Elemental composition of coatings on samples of steel 15HGN2TA

Table 1

\begin{tabular}{|l|c|c|c|c|c|c|c|c|}
\hline \multirow{2}{*}{ Sample } & \multicolumn{7}{c|}{ Chemical element \% } \\
\cline { 2 - 11 } & Fe & $\mathrm{Cr}$ & $\mathrm{Mn}$ & $\mathrm{Ni}$ & $\mathrm{Si}$ & $\mathrm{Ti}$ & $\mathrm{W}$ & $\mathrm{O}$ \\
\hline Steel 15HGN2TA (initial) & 95,3 & 1,09 & 1,95 & 1,66 & - & - & - & - \\
\hline Coating of LE T15K6 & 54,87 & - & - & - & - & 12,34 & 32,8 & - \\
\hline Coating of LE IMH2 & 23,73 & 14,39 & - & 58,02 & 3,86 & - & - & - \\
\hline Coating LE Ш2 & 47,05 & - & - & 7,32 & - & 29,56 & - & 16,07 \\
\hline
\end{tabular}

The study also allowed to determine the characteristic size of the structural elements (D), the height parameters of the surface roughness: the arithmetic mean deviation of the profile ( $\mathrm{Ra}$ ), the depth of the largest depression (Rv) and the height of the largest protrusion (Rp) of the sample surfaces (Table 2). 
Analysis of the obtained values of the roughness parameters of the studied surfaces shows that the parameters: Ra, Rp and Rv vary depending on the electrode material. The parameters are increased in the following order: the initial state of the surface $\rightarrow$ treatment with the electrode T15K6 $\rightarrow$ treatment with the electrode W2 $\rightarrow$ treatment with the electrode IMX2 (Table 2). In this case, the parameter Ra increases by 1.5-3.9 times. The largest increase in the roughness parameter Ra to 6.3 and the RR parameter to $538.3 \mathrm{~nm}$ is observed when treated with the electrode IMX2. This may be due to the higher level of energy action at the EET by this electrode.

The obtained values (Table 2) of the characteristic dimensions of the structural elements of the surface show that in the modified samples in comparison with the initial state, they decrease by 8-13 times. The minimum dimensions of the parameter D are obtained by processing the electrode W2.

In order to study the effect of frictional interaction of polymer counter-samples with metal samples after their EIO on the topography of friction surfaces, a study of friction surfaces on atomic force (k-AFM) and scanning electron microscopes was performed (Fig. 4, 5).

Table 2

Surface parameters of the initial and modified samples

\begin{tabular}{|c|c|c|c|c|}
\hline Sample / Parameter & $\begin{array}{c}\text { Typical structure size } \\
\mathrm{D}, \mathrm{nm}\end{array}$ & $\mathrm{Ra}, \mu \mathrm{m}$ & $\begin{array}{c}\text { Height of the largest } \\
\text { protrusion of the profile } \\
\mathrm{Rp}, \mathrm{nm}\end{array}$ & $\begin{array}{c}\text { Depth of the largest } \\
\text { depression of the profile Rv, } \\
\mathrm{nm}\end{array}$ \\
\hline $\begin{array}{c}\text { Steel 15XГH2TA } \\
\text { (initial) }\end{array}$ & $2000-2500$ & $\approx 1,6$ & 379,0 & 344,8 \\
\hline Coating LE T15K6 & $200-250$ & $\approx 2,5$ & 477,3 & 378,5 \\
\hline Coating LE Ш2 & $150-200$ & $\approx 3,2$ & 504,1 & 485,7 \\
\hline $\begin{array}{c}\text { Coating of LE } \\
\text { IMH2 }\end{array}$ & $250-300$ & $\approx 6,3$ & 538,3 & 484,4 \\
\hline
\end{tabular}

The images of the surfaces of the samples obtained by contact atomic force microscopy show that the topography of the surfaces on the friction track and outside the track differ (Fig. 4). The figure shows that the height of surface irregularities in areas after friction is higher than in areas outside the friction track. This may be due to the formation on the surface of the samples of the friction transfer film.
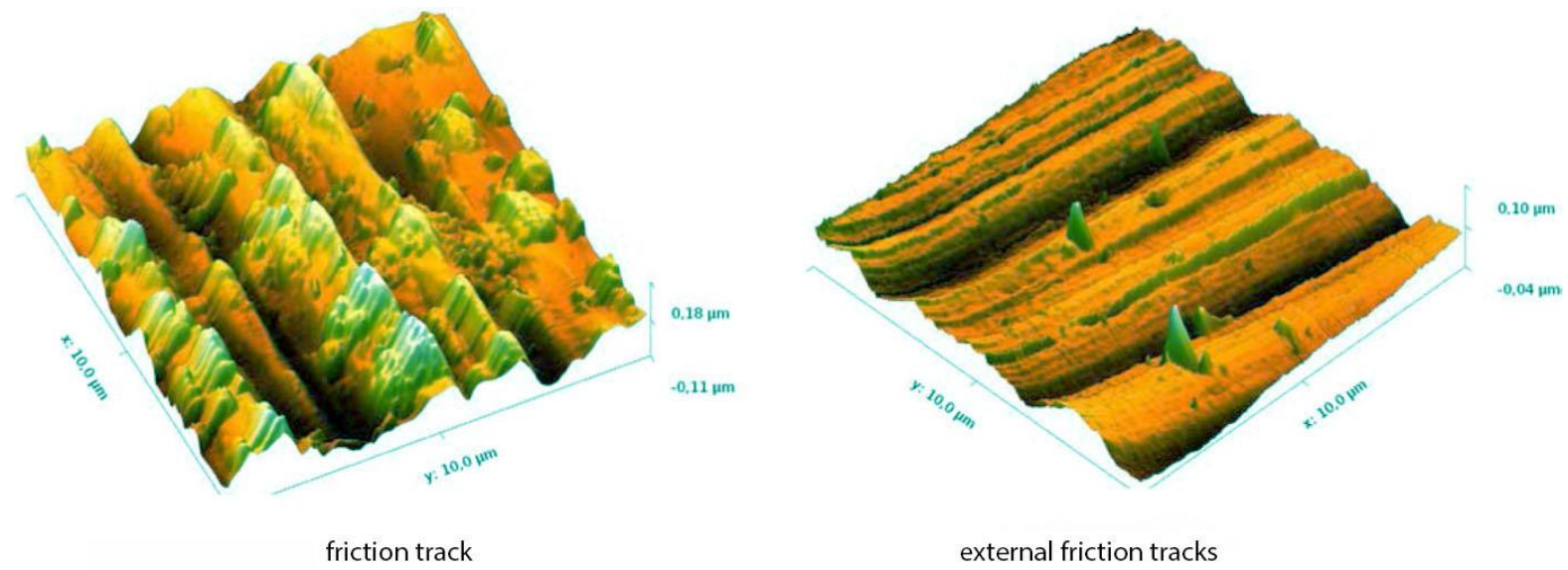

Fig. 4. Topography of the surface of the sample of steel 15HGN2TA, treated with the electrode IMX2 $\left(\mathrm{U}=120 \mathrm{~B} ; \mathrm{C}=150 \mu \mathrm{F} ; \mathrm{t}=4 \mathrm{~min} / \mathrm{cm}^{2}\right)$, after friction and wear tests

In Fig. 5 shows images of surfaces after tribotechnical tests obtained by scanning electron microscopy. The surface areas of the samples on the friction track are markedly different from the surface areas outside the track. The friction transfer polymer film (FP), structured in the sliding direction, is clearly visible on the friction track section. In the area near the friction track there is an island coating without a film of AF. Thus, it was found that the frictional interaction of steel samples treated by the EET method with polymeric countersamples on the friction surface of steel samples forms a thin film of FP, which leads to a change in surface topography with increasing microroughness and structuring of the transfer film in the sliding direction.

Tribotechnical properties of steel-based structures at EET were evaluated by the wear rate of polymeric counter-samples during sliding friction on the modified surface of steel samples. Steel samples were treated with 
an electrode IMX2. In order to get a clear idea of the influence of the level of energy action on the wear resistance (wear rate) of the friction pair, the dependences $J=f(E)$ were constructed according to the test results (Fig. 6).

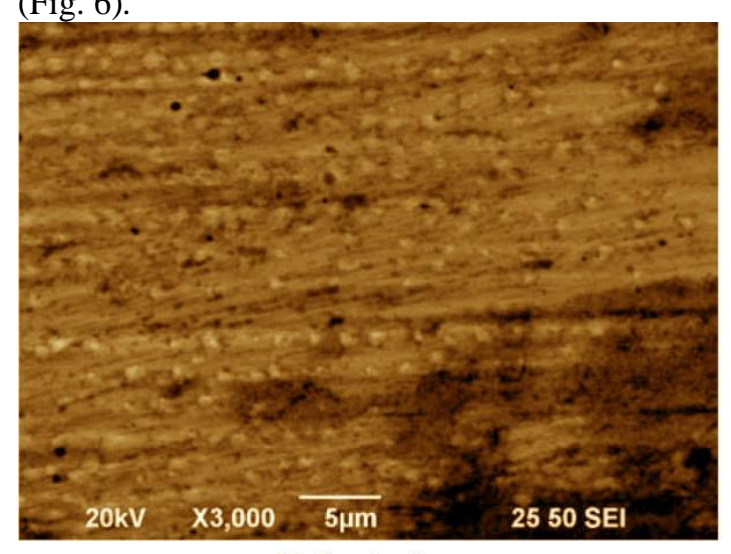

friction track

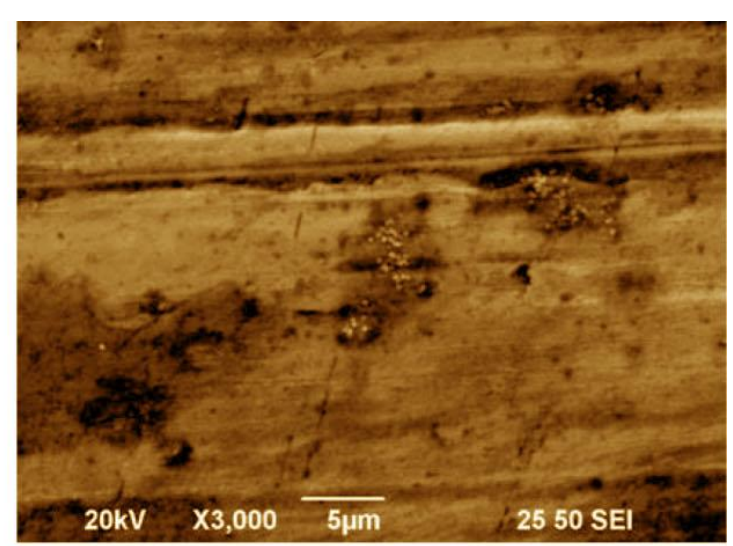

external friction tracks

Fig. 5. The surface of the sample made of steel 15HGN2TA, treated with an electrode IMX2 $\left(\mathrm{U}=120 \mathrm{~V} ; \mathrm{C}=150 \mu \mathrm{F} ; \mathrm{t}=4 \mathrm{~min} / \mathrm{cm}^{2}\right)$, after tests for friction and wear

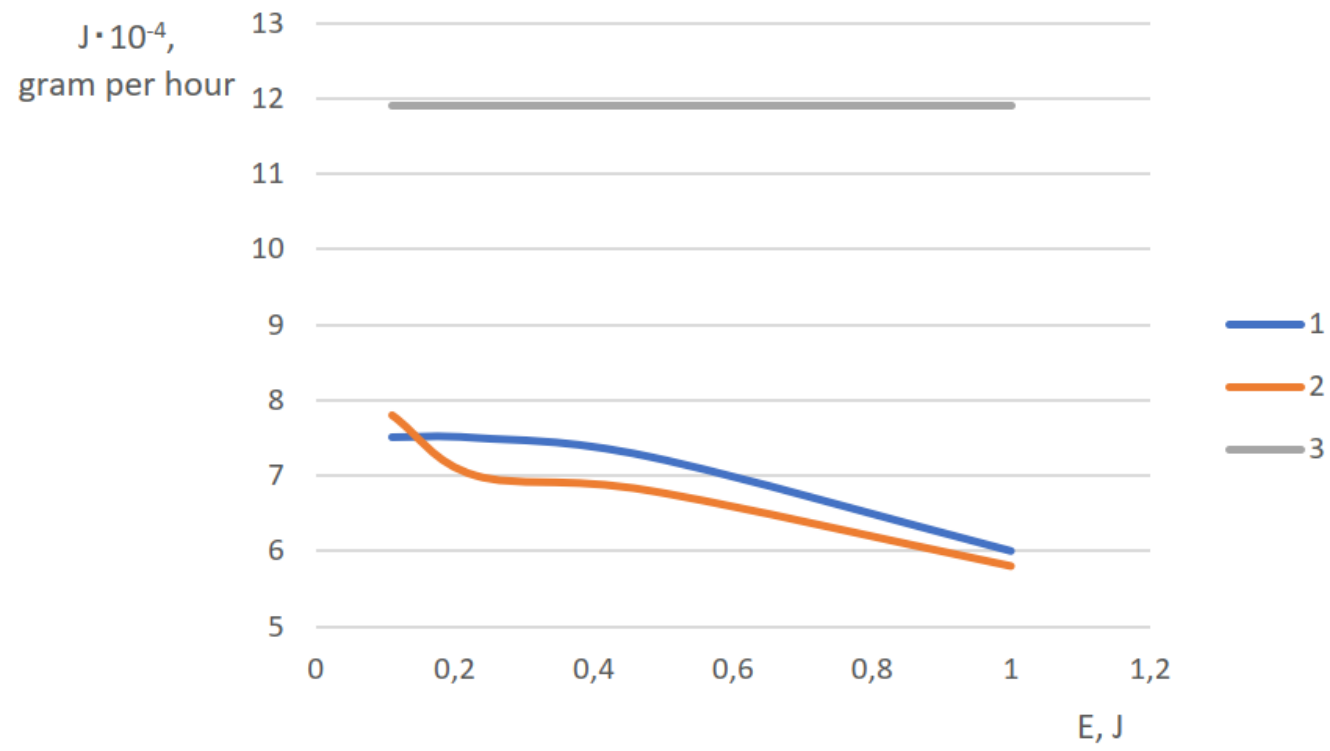

Fig. 6. Dependence of wear rate of polymeric countersamples on pulse energy at EET of samples from steel 15HGN2TA:

1 - samples with EET duration of $4 \mathrm{~min} / \mathrm{cm}^{2} ; 2$ - samples with EET duration of $5 \mathrm{~min} / \mathrm{cm}^{2}$; 3 - hardened sample without EET

The obtained dependences allow us to conclude that with increasing pulse energy in the EET of steel samples, the wear rate of the polymer countersample decreases by 1.2-1.3 times. At the same time, the increase in the duration of EET has a negligible effect on the wear rate of polymeric counter samples (by $\sim 3 \%$ ). It was also shown that the wear rate of metal-polymer friction pair with samples modified by EET is less than this parameter in friction pairs with hardened sample, approximately 1.6-2 times.

\section{Conclusions}

By the method of X-ray phase analysis of the surfaces of the modified samples, the regularities of the formation of coatings of different phase composition depending on the chemical composition of LE are established, which consist in the fact that the phase composition of coatings is determined by the chemical composition of LE.

It is established that the thickness of the molded coating depends on the chemical composition of the material of the alloying electrode and energy regimes EET: the largest coating thickness is formed when processing the electrode IMX2, which is 4 times more than when processing serial electrode T15K6; increasing the energy modes of EET leads to an increase in the thickness of the coating regardless of the material of LE, 
which allows us to recommend EET electrodes T15K6, IMH2, Sh2 to increase wear resistance and restore worn surfaces of parts of the friction units of machines.

It is established that the microhardness of coatings depends on the modes of EET and the material of the alloying electrode; experimental dependences of microhardness of coatings on voltage and discharge capacitance of capacitors have extreme character with maxima at voltage $\mathrm{U}=120-140 \mathrm{~V}$ and discharge capacity $\mathrm{C}=120 \mathrm{uF}$.

The method of contact atomic force microscopy revealed a significant (8-13 times) reduction in the characteristic size of the structural elements (D) in the coatings formed by the EET by different electrodes, compared with the original (unmodified) surface. It is also established that at EET surfaces with height parameters of roughness ( $\mathrm{Ra}, \mathrm{Rv}, \mathrm{Rp}$ ), characteristic and commensurate with similar parameters of the surface received at finishing machining are formed. In this case, as a result of the EET electrode IMH2 there is the largest increase in the roughness parameter Ra 3.9 times, which is due to the higher level of energy action during treatment with this alloying electrode.

\section{References}

1. Dolbilin E.V. Himiko-termicheskaja obrabotka metallov v jelektricheskom razrjade / E.V. Dolbilin. M.: MJeI, 2001. $-298 \mathrm{~s}$.

2. Eighteenth International Conference on Numerical Simulation of Plasmas (ICNSP'03) and US-Japan simulation workshop "Scope of Simulation Science", 7-10 September 2003, Cape Cod, Massachusetts USA.

3. Celebration of High Temperature Plasma Physics, 5-7 June 2002, Princeton Plasma Physics Laboratory, Princeton, New Jersey USA. Contact Dolores Lawson, MS37, Princeton Plasma Physics Laboratory, P.O. Box 451, Princeton, New Jersey 08543 USA.

4. Gitlevich A.E. Jelektroiskrovoe legirovanie metallicheskih poverhnostej / A.E. Gitlevich, V.V. Mihajlov, N.Ja. Carkanskij. - Kishinev: Izd-vo AN MSSRJu, 1985. - 387 s.

5. Marchenko D.D. Improving the contact strength of V-belt pulleys using plastic deformation / D.D. Marchenko, K.S. Matvyeyeva // Problems of Tribology. - Khmelnitsky, 2019. - Vol 24. - No 4/94 (2019) - S. 49-53. DOI: https://doi.org/10.31891/2079-1372-2019-94-4-49-53.

6. Butakov B.I. Usovershenstvovanie processa chistovogo obkatyvanija detalej rolikami / B.I. Butakov // Vestnik mashinostroenija. - 1984. - № 7. - S. 50 - 53.

7. Marchenko D.D. Investigation of tool wear resistance when smoothing parts / D.D. Marchenko, K.S.Matvyeyeva // Problems of Tribology. - Khmelnitsky, 2020. - Vol 25. - No 4/98 (2020) - S. 40-44. DOI: https://doi.org/10.31891/2079-1372-2020-98-4-40-44

8. Dykha A.V. Study and development of the technology for hardening rope blocks by reeling. ISSN 1729-3774 / A.V. Dykha, D.D. Marchenko, V.A. Artyukh, O.V. Zubiekhina-Khaiiat, V.N. Kurepin // EasternEuropean Journal of Enterprise Technologies. Ukraine: PC «TECHNOLOGY CENTER». - 2018. - №2/1 (92) 2018. - pp. 22-32. DOI: https://doi.org/10.15587/1729-4061.2018.126196.

9. Dykha A.V. Prediction the wear of sliding bearings. ISSN 2227-524X / A.V. Dykha, D.D. Marchenko // International Journal of Engineering and Technology (UAE). India: "Sciencepubco-logo" Science Publishing Corporation. Publisher of International Academic Journals. - 2018. - Vol. 7, No 2.23 (2018). - pp. 4-8. DOI: https://doi.org/10.14419/ijet.v7i2.23.11872.

10. Marchenko D.D. Analysis of the influence of surface plastic deformation on increasing the wear resistance of machine parts / D.D. Marchenko, V.A. Artyukh, K.S. Matvyeyeva // Problems of Tribology. Khmelnitsky, 2020. - Vol 25. - No 2/96 (2020) - S. 6-11. DOI: https://doi.org/10.31891/2079-1372-2020-96-26-11. 
Марченко Д.Д., Матвєєва К.С. Трибологічні дослідження електроерозійної обробки стальних деталей машин.

В статті розглянута технологія електроерозійної обробки сталевих пар тертя і приведені результати експериментальних досліджень. Аналіз експериментальних досліджень показав, що збільшення анодно-катодної напруги призводить до різкого зниження мікротвердості поверхневого шару. Виконане дослідження дозволило також визначити характерний розмір структурних елементів, висотні параметри шорсткості поверхні. Елементний склад початкової поверхні зразка із сталі 15ХГН2ТА відрізняється від складу покриттів i поверхневих шарів зразків, модифікованих електроерозійної обробки різними електродами. У режимі роботи системи «анод - катод» на поверхні катода внаслідок дисипативних процесів формується тонкий шар покриття стійкої модифікованої структури. Показано, що висота нерівностей поверхні на ділянках після тертя вище, ніж на ділянках поверхні поза доріжкою тертя, що пов'язано з формуванням на поверхні зразків плівки фрикційного перенесення. Виявлено, що при фрикційній взаємодії сталевих зразків, оброблених електроерозійним методом на поверхні тертя сталевих зразків формується тонка плівка, що призводить до зміни топографії поверхонь зі збільшенням висоти мікронерівностей і структуризацією плівки перенесення у напрямі ковзання. Встановлено вплив режимів електроерозійної обробки сталевих поверхонь на зносостійкість металополімерної трібосистеми та отримані оптимальні режими обробки: напруга $U=145-150 \mathrm{~B}$, місткість конденсаторів $C=225-230$ мкФ, тривалість обробки $t=3-4$ хв $/ \mathrm{cm}^{2}$, що забезпечують найбільше зниження швидкості зношування полімерного контртіла і рекомендовані при розробці технологічних процесів електроерозійної обробки.

Ключові слова: знос, електрод, шорсткість, зносостійкість, пара тертя, покриття, електроерозійна обробка.. 